\title{
Zastosowanie technologii CRISPR/Cas9 w leczeniu nowotworów
}

\section{Application of CRISPR/Cas9 technology in cancer treatment}

\author{
Julia Ostapowicz ${ }^{1,2}$, Kamila Romanowska ${ }^{1,2}$, \\ Wojciech Golusiński ${ }^{1}$ \\ ${ }^{1}$ Katedra i Klinika Chirurgii Gtowy, Szyi i Onkologii Laryngologicznej, \\ Uniwersytet Medyczny im. Karola Marcinkowskiego w Poznaniu, Wielkopolskie Centrum Onkologii \\ ${ }^{1}$ Zakład Fizyki Medycznej, Pracownia Radiobiologii, \\ Uniwersytet Medyczny im. Karola Marcinkowskiego w Poznaniu, Wielkopolskie Centrum Onkologii
}

\section{Streszczenie}

Wprowadzenie technik edycji genomu jako podstawowego narzędzia w badaniach naukowych wywołało znaczny postęp w naukach biologicznych, medycznych oraz pozwoliło zrozumieć patofizjologię wielu chorób. Jedną z najnowocześniejszych metod wprowadzania specyficznych zmian w genomie jest obecnie technologia CRISPR/Cas9, która poprzez insercję, delecję lub zamianę nukleotydów w sekwencji DNA prowadzi do inaktywacji genów docelowych, nabycia nowych cech genetycznych lub korekty niepożądanych mutacji. Ponadto, technologia CRISPR/Cas9 pozwala na tworzenie modeli in vitro i in vivo wielu chorób, a następnie dokładne badanie mechanizmów ich powstawania. Obecnie prowadzonych jest wiele badań w dziedzinie onkologii wykorzystujących technikę CRISPR/Cas9, a niniejsza praca jest ich zwięzłym podsumowaniem.

\begin{abstract}
Genome editing techniques as a basic tools in scientific research has resulted in significant advances in biological and medical sciences, and has made it possible to understand the pathophysiology of many diseases. One of the most up-to-date method of introducing specific changes in the genome is the CRISPR/ Cas9 technology, which, by inserting, deleting or changing nucleotides in the DNA sequence, leads to inactivation of target genes, acquisition of new genetic features or correction of unwanted mutations. In addition, the CRISPR/Cas9 technology allows the creation of in vitro and in vivo models of many diseases, and the detailed study of their patomechanisms. Currently, there are many studies in the field of oncology using the CRISPR/Cas9 technique, and this work is a brief summary of them.
\end{abstract}

Adres do korespondencji

Kamila Romanowska

Pracownia Radiobiologii,

Wielkopolskie Centrum Onkologii, ul. Garbary 15, 61-866 Poznań, Polska

e-mail: kamromanowska@gmail.com 
Słowa kluczowe: CRISPR/Cas9; onkologia

Keywords: CRISPR/Cas9; oncology

\section{Wprowadzenie}

Odkrycie technologii CRISPR/Cas9 jako narzędzia do edytowania genomu było rewolucją w naukach biologicznych i wywołało niezwykłe zainteresowanie, jako potencjalne narzędzie do wykorzystania w terapii genowej. Prostota wykorzystania tej technologii sprawiła, że jest ona szeroko stosowana w wielu dziedzinach nauki m.in. do badania patomechanizmów wielu chorób, tworzenia modelowych linii komórkowych oraz badania zmian epigenetycznych (1). Metoda ta jest również szeroko stosowana w inżynierii molekularnej do wywoływania celowanych modyfikacji genetycznych (2). CRISPR (ang. Clustered Regularly Interspaced Short Palindromic Repeat), oznacza zgrupowane, regularnie rozproszone, krótkie, powtarzające się sekwencje palindromowe. Powtórzenia te zostały zidentyfikowane w bakterii Escherichia coli w 1987 r. przez japońskiego badacza Yoshizumi Ishino (3). Klastry powtórzeń CRISPR oddzielone są niepowtarzalnymi sekwencjami DNA nazwanymi spacerami lub przerywnikami. Dopiero po latach odkryto, że fragmenty DNA zgrupowane w genomie bakterii pochodzą oryginalnie od bakteriofagów- wirusów atakujących bakterie. Dzięki komputerowym analizom sekwencji CRISPR udowodniono, że są one obecne w genomie większości bakterii i archeonów, a ponadto są związane z genami cas (ang. CRISPR-associated) (4). Produkty białkowe tych genów to enzymy Cas, które uczestniczą w obronie przed fagami. Wspólne działanie sekwencji CRISPR i białek Cas stanowi nabyty układ odpornościowy prokariotów i działa podobnie do eukariotycznego systemu iRNA (ang. interference RNA, interferencyjnego RNA) (5). Geny cas zostały podzielone początkowo na cztery grupy ze względu na swoją konserwatywność i produkty białkowe: Cas1, Cas2, Cas3, Cas4. Późniejsze analizy wykazały, że w genomach różnych organizmów zawierających sekwencje CRISPR występuje wiele form białek Cas, które można zakwalifikować do różnych rodzin (6). Dalsze analizy sekwencji genów cas pozwoliły na wyodrębnienie dodatkowych rodzin tych genów. Po dokładniejszych badaniach stwierdzono, że białka Cas3 posiadają motywy charakterystyczne dla helikaz RNA, a Cas4 mają właściwości egzonukleaz. W 2007 r. wykonano badania potwierdzające, że główną funkcją systemu CRISPR/Cas jest obrona bakterii przed zakażeniami wirusowymi. Eksperyment polegał na wstawieniu sekwencji fagowej do regionu spacer'a CRISPR genomu bakterii Streptococcus thermophilus, co w konsekwencji uczyniło ten szczep odpornym na obecność faga (7). Późniejsze prace wykazały, że cas9 jest genem niezbędnym do interferencji kodowanej przez CRISPR.

\section{CRISPR/Cas - narzędzie do edycji genomu}

Klasyfikacja systemów CRISPR-Cas obejmuje obecnie dwie klasy, utworzone ze względu na białka efektorowe. Do technik edytowania genomu częściej używana jest klasa II pochodząca od bakterii Streptococcus pyogenes (4). Spośród tej klasy najlepiej poznanym jest białko Cas9, czyli białko efektorowe o aktywności endonukleazy. Działanie systemu CRISPR-Cas9 rozpoczyna się od transkrypcji regionów CRISPR, oraz powstania cząsteczek tracrRNA (ang. trans-activating crRNA), które rozpoznają sekwencję docelowego DNA. Transkrypcja regionów CRISPR skutkuję powstaniem krótkich cząsteczek RNA, zwanych CRISPR RNA (ang. crRNA), które służą do identyfikacji i degradacji obcego DNA lub RNA. Sekwencja crRNA określa specyficzność działania nukleazy (8). Kompleks crRNA-tracrRNA-Cas9 ma zdolność cięcia obcego DNA w ściśle określonym miejscu, początkowo przyłączając się do sekwencji PAM (ang. protospacer adjacent motif), czyli trzynukleotydowej sekwencji 5'-NGG-3', a następnie rozpoznania docelowego DNA przez crRNA na zasadzie komplementarności zasad. TracrRNA kieruje białko Cas w miejsce połączenia się crRNA oraz docelowego DNA. Białko Cas9 zawiera dwie domeny REC (ang. recognition) i NUC (ang. nuclease). Domena REC odpowiada za rozpoznanie kwasu nukleinowego, a NUC zawiera nukleazy RuvC i HNH, które tną podwójną helisę DNA. W konsekwencji powstaje dwuniciowe pęknięcie w docelowym DNA, które jest rozpoznawane w komórce jako obce. W domenie NUC znajduje się region C-końcowy zawierający domenę PI (ang. PAM-interacting) zbudowaną z 269 aminokwasów(9), która rozpoznaje sekwencję PAM w obcym DNA (5). 
Prostota systemu CRISPR/Cas9 wpłynęła na zrewolucjonizowanie inżynierii genetycznej i pozwoliła na edytowanie genomu wielu komórek i organizmów (10). W inżynierii genetycznej połączenie tracrRNA oraz crRNA nazywane jest sgRNA (ang. single guide RNA). W celu edycji genomu należy do komórki docelowej dostarczyć sgRNA, który łączy się z docelową sekwencją w wybranym genie, na zasadzie komplementarności. Rozpoznanie sekwencji docelowej oraz jej cięcie przez białko Cas9, wymaga obecności sekwencji PAM w docelowym DNA (11). Wybór metody wprowadzania tych elementów do komórek docelowych zależy od ich typu. Do komórek należy wprowadzić kilka komponentów, aby uzyskać pożądany efekt np. terapeutyczny. Do stosowanych obecnie metod należy transdukcja komórek wektorami wirusowymi. Najczęściej wykorzystywane są wektory lentiwirusowe i adenowirusowe (12). Jednakże, wprowadzanie systemu CRISPR/Cas do komórek może odbywać się także na drodze elektroporacji, mikroiniekcji oraz wykorzystania struktur liposomowych np. nanocząsteczek lipidowych (ang. lipid nanoparticles, LNPs).

Tabela 1. Zestawienie najczęściej wykorzystywanych sposobów wprowadzania CRISPR/Cas do komórek docelowych

\begin{tabular}{|c|c|c|c|c|}
\hline $\begin{array}{c}\text { Sposób } \\
\text { wprowadzania do } \\
\text { komórek }\end{array}$ & Zalety & Wady & Zastosowanie & Referencja \\
\hline AAV & $\begin{array}{l}\text { Powinowactwo } \\
\text { do wielu typów } \\
\text { komórek }\end{array}$ & $\begin{array}{l}\text { Konieczna obecność } \\
\text { wirusa pomocniczego }\end{array}$ & in vivo & (13) \\
\hline Lentiwirusy & Stała ekspresja & $\begin{array}{l}\text { Brak transfekcji dzielących } \\
\text { się komórek }\end{array}$ & in vitro i ex vivo & (14) \\
\hline Adenowirusy & $\begin{array}{l}\text { Powinowactwo } \\
\text { do wielu typów } \\
\text { komórek }\end{array}$ & Przejściowa ekspresja & in vivo & (15) \\
\hline Liposomy & Mała toksyczność & $\begin{array}{c}\text { Efektywność zależna od } \\
\text { typu komórek }\end{array}$ & in vitro i in vivo & (16) \\
\hline Elektroporacja & $\begin{array}{l}\text { Wydajne } \\
\text { wprowadzanie do } \\
\text { komórek }\end{array}$ & $\begin{array}{c}\text { Może wywoływać efekty } \\
\text { toksyczne i prowadzić do } \\
\text { stałej permeabilizacji błony } \\
\text { komórkowej }\end{array}$ & in vitro i ex vivo & (17) \\
\hline Mikroiniekcja & $\begin{array}{l}\text { Bezpośrednie } \\
\text { wprowadzanie do } \\
\text { komórek }\end{array}$ & Duże wymogi technicznie & in vitro i ex vivo & (18) \\
\hline
\end{tabular}

Wprowadzeniekompleksu sgRNAi ibiałka Cas9 dokomórek docelowych powoduje powstanie dwuniciowych pęknięć w DNA, które mogą być naprawione przez dwa systemy: NHEJ (ang. non-homologous end-joining, łączenie niehomologicznych końców) i HDR (ang. homology-directed repair, homologiczna rekombinacja). System naprawy NHEJ poprzez łączenie niehomologicznych końców DNA powoduje insercje lub delecje. Mechanizm NHEJ jest podatny na błędy i może prowadzić do mutacji z przesunięciem ramki odczytu, skutkując przedwczesnym powstaniem kodonu STOP i powstawaniem niefunkcjonalnego polipeptydu (19). W przypadku mechanizmu NHEJ możliwe jest wyłączenie funkcji genów (ang. knock-out). Z kolei, na drodze mechanizmu HDR nić DNA odtwarzana jest z użyciem częściowo komplementarnej sekwencji co umożliwia wprowadzanie specyficznych mutacji (20). Figura 1 przedstawia podsumowanie zastosowania systemu CRISPR/Cas9 w inżynierii genetycznej.

Obecnie największym wyzwaniem w stosowaniu metody CRISPR/Cas9 jest bezpiecznie i efektywne wprowadzenie komponentów systemu do komórek docelowych (21). W 2016 r. w Chinach, po raz pierwszy wykorzystano tę technologię jako terapię przeciwnowotworową u pacjenta z agresywnym rakiem płuca (22). 


\section{Wykorzystanie systemu CRISPR/Cas9 w inżynierii genetycznej}

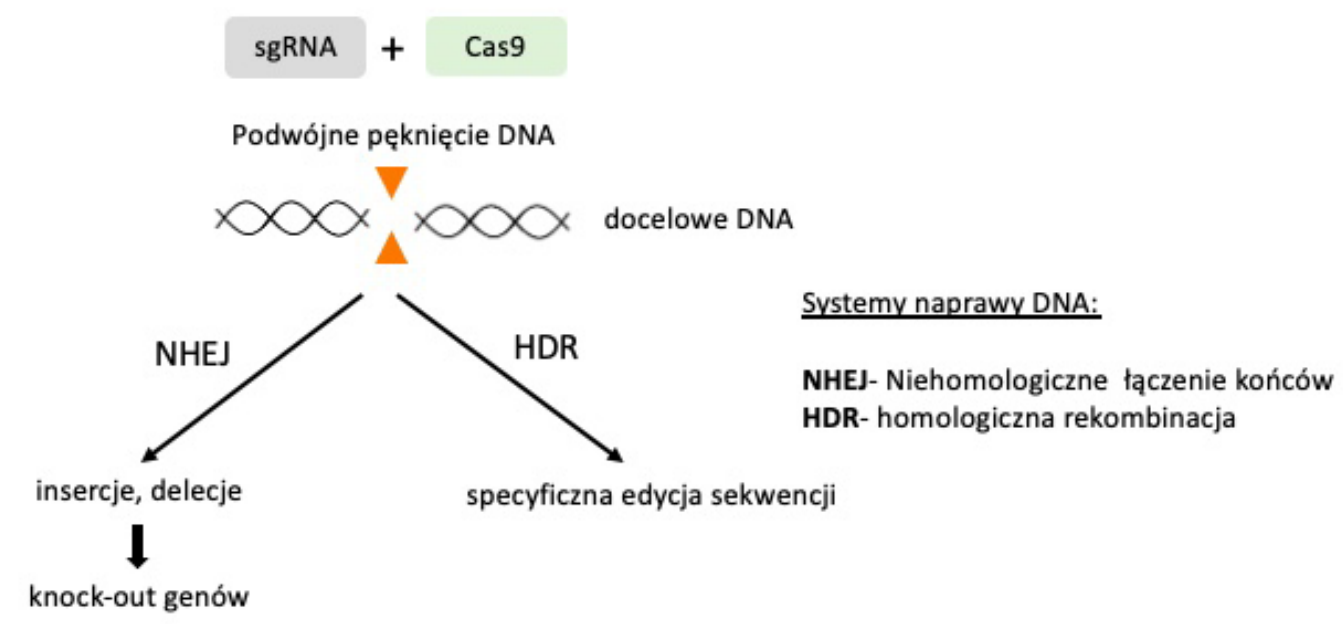

Figura 1. Wykorzystanie systemu CRISPR/Cas9 w inżynierii genetycznej.

\section{Wykorzystanie technologii CRISPR/Cas9 w badaniach nad nowotworami}

Technologia edycji genomu z wykorzystaniem systemu CRISPR/Cas9 jest szeroko stosowana w badaniach nad patogenezą i rozwojem nowotworów. Technologia ta pozwala na generowanie modeli komórkowych lub zwierzęcych różnych chorób i w ten sposób poznanie mechanizmu ich działania (23). CRISPR/Cas9 indukuje ukierunkowane zmiany genetyczne w komórkach, które mogą prowadzić do nowotworzenia. Dzięki badaniom przeprowadzonym na mysim modelu chorób nowotworowych odkryto geny podnoszące wrażliwość, albo powodujące oporność na immunoterapię. Do tych genów należy gen Ptpn2, kodujący fosfatazę zaangażowaną w procesy sygnałowe komórek oraz Ripk1, gen kinazy regulującej śmierć komórkową i stan zapalny (24). Inne badania obrazują wykorzystanie metody CRISPR do knock-out'u zmutowanego genu Kras w komórkach nowotworowych trzustki, co może prowadzić do ich wolniejszego wzrostu (25). Knock-out genu KDM6A (demetylazy histonów) w komórkach nowotworowych trzustki doprowadził do zwiększenia agresywnego fenotypu tych komórek podczas gdy jego nadekspresja go tłumiła (26). Technologia CRISPR/Cas9 pozwala na stabilne wyciszenie genów w komórkach oraz badanie mechanizmów powstawania oporności na terapie przeciwnowotworowe. W linii komórkowej płaskonabłonkowego raka głowy i szyi (HNSCC, ang. Head and Neck Squamous Cell Carcinoma) dokonano wyciszenia ekspresji genów CD98hc i LAT1, które razem tworzą transbłonowy transporter aminokwasów, a podwyższony poziom mRNA genu $S L C 3 A 2$, kodującego łańcuch ciężki białka CD98, wiąże się z gorszym rokowaniem dla pacjentów. Dowiedziono, że wysoki poziom ekspresji CD98hc i LAT1 jest znacząco skorelowany ze wzorestem radiooporności w modelach in vivo i in vitro HNSCC (27). Dzięki metodzie CRISPR możliwa jest klasyfikacja mikroRNA związanych z nowotworami. $\mathrm{W}$ badaniu przeprowadzonym z wykorzystaniem ludzkiej linii komórkowej raka prostaty dowiedziono, że zaburzona ekspresja dwóch miRNA (miR-663a i miR-1225-5p) wpływa na progresję raka prostaty i może być wykorzystana jako potencjalny marker tego nowotworu (28). Nabranie przez komórki nowotworowe cech komórek macierzystych jest jak dotąd słabo poznane, ale wiadomo, że wpływa to na agresywny fenotyp i oporność na leczenie. W badaniu nad neuroendokrynnym rakiem prostaty indukowanym terapią t-NEPC (ang. therapyinduced neuroendocrine prostate cancer) stwierdzono, że gen LIN28B wpływa na indukcję sieci połączeń przypominającą tę w komórkach macierzystych oraz ma wpływ na morfologię komórek neuroendokrynnych. Wyciszenie LIN28B hamowało procesy związane z rozwojem guza w ksenograficznych modelach (29). Dzięki technologii CRISPR/Cas9 poszukuje się genów odpowiedzialnych za progresję czerniaka. Dotychczas dzięki zahamowaniu funkcji genu ptgs2 w mysich komórkach czerniaka udowodniono, że gen ten wpływa na 
proliferację, migrację i inwazyjność komórek nowotworowych. Jego knock-out spowodował zmniejszenie rozwoju guza i jego przerzutowanie in vivo (30) . Odkrycie to wskazuje, że gen ptgs2 może być celem molekularnym dla nowych terapii przeciwnowotworowych, w tym dla czerniaka skóry. W tabeli zebrano przykłady wykorzystania technologii CRISPR/Cas9 do badań nad nowotworami.

Tabela 2. Wykorzystanie CRISPR/Cas9 w badaniach nad nowotworami.

\begin{tabular}{|c|c|c|c|c|}
\hline $\begin{array}{c}\text { Rodzaj } \\
\text { nowotworu }\end{array}$ & $\begin{array}{c}\text { Zastosowanie } \\
\text { CRISPR }\end{array}$ & In vivo/ In vitro & Wynik & Referencja \\
\hline Czerniak & $\begin{array}{c}\text { knock-out/ } \\
\text { screening }\end{array}$ & in vivo & $\begin{array}{c}\text { Odkrycie genów związanych z } \\
\text { opornością na terapię }\end{array}$ & $(24)$ \\
\hline Rak trzustki & knock-out & in vitro & $\begin{array}{c}\text { Wyciszenie zmutowanego Kras } \\
\text { prowadzi do wolniejszego wzrostu } \\
\text { komórek nowotworowych; } \\
\text { Wyciszanie KDM6A prowadzi do } \\
\text { wzrostu agresywności nowotworu }\end{array}$ & (25) \\
\hline $\begin{array}{c}\text { Płaskonabłonkowy } \\
\text { rak głowy i szyi }\end{array}$ & knock-out & in vitro i in vivo & $\begin{array}{c}\text { Korelacja poziomu ekspresji } \\
\text { CD98hc i LAT1 z radioopornością }\end{array}$ & (27) \\
\hline Rak prostaty & knock-out/ & in vitro & $\begin{array}{c}\text { Zaburzenie ekspresji wybranych } \\
\text { miRNA wplywa na progresję raka } \\
\text { prostaty }\end{array}$ & (28) \\
\hline $\begin{array}{c}\text { Neuroendokrynny } \\
\text { rak prostaty }\end{array}$ & knock-out & in vivo & $\begin{array}{c}\text { Wyciszenie genu LIN28 wpływa na } \\
\text { hamowanie wzrostu guza }\end{array}$ & $(29)$ \\
\hline \multicolumn{2}{c|}{ kzerniak } & in vitro i in vivo & $\begin{array}{c}\text { Zahamowanie ekspresji genu ptgs2 } \\
\text { wpływa na zmniejszenie rozmiaru } \\
\text { guza }\end{array}$ & (30) \\
\hline
\end{tabular}

\section{Zalety i ograniczenia metody CRISPR/Cas9}

CRISPR/Cas9 jest metodą, która pozwala na precyzyjne i wszechstronne edytowanie genomu (31). Jedną z zalet tej metody jest niewątpliwie ogromny wpływ na rozwój wiedzy odnośnie mechanizmów związanych z nowotworzeniem. Metoda CRISPR/Cas9 pozwana na screening genów, które potencjalnie mogą być zaangażowane w różne procesy biologiczne (32). Dodatkowo w porównaniu do innych metod edycji genomu CRISPR może być użyty w technice multiplex, czyli jednoczesnym wyciszaniu kilku genów (33). System ten wydaje się mieć obiecujące zastosowanie w leczeniu zakażeń wirusowych. Zanim jednak technologia ta będzie mogła być używana w celach terapeutycznych na szeroką skalę kliniczną, koniecznie jest opracowanie efektywnych metod dostarczania jej komponentów do komórek oraz zapewnienie specyficznego działania, aby uniknąć zaburzenia funkcji innych genów (efekt off-target) (34). Aby zminimalizować działanie off-target powstały specjalnie udoskonalone warianty białka Cas9, które cechują się m.in. ulepszonym rozpoznawaniem sekwencji PAM lub indukujące pęknięcia jednoniciowe w DNA (SSBs, ang. single-stranded breaks) (19). W uniknięciu efektów off-target sprzyja także dobre zaprojektowanie i optymalizacja sekwencji sgRNA. Dużym ograniczeniem stosowania metody CRISPR/Cas9 w terapii genowej jest także sposób dostarczenia komponentów systemu do komórek docelowych. Metoda dostarczania z użyciem wektorów wirusowych jest najbardziej wydajna, ale może skutkować pojawieniem się immunogenności. Z kolei nie-wirusowe metody, mimo mniejszej immunogenności, cechują się także dużo niższą wydajnością (19). Rozwiązaniem może być pobieranie komórek od pacjenta, modyfikacja ich ex vivo i ponowne wprowadzenie do organizmu. Metoda ta może być stosowana w przypadku komórek, które są w stanie przetrwać i namnażać się w warunkach hodowli komórkowej np. limfocyty T (35). 


\section{Podsumowanie}

Technologia CRISPR/Cas9 jest obiecującym narzędziem, które w przyszłości posłużyć może do leczenia wielu chorób. Zanim system ten będzie mógł być używany w celach terapeutycznych na szeroką skalę kliniczną, koniecznie jest opracowanie efektywnych metod dostarczania go do komórek oraz zapewnienie specyficznego działania, aby uniknąć zaburzenia funkcji innych genów (efekt off-target). Coraz częściej poruszane są także kwestie etyczne związane z edytowaniem genomu z wykorzystaniem populacyjnym technologii CRISPR/Cas9 (36).

\section{Bibliografia}

[1] Lino CA, Harper JC, Carney JP, Timlin JA. Delivering CRISPR: a review of the challenges and approaches. Drug Deliv. 25 maj 2018;25(1):1234-57.

[2] Koujah L, Shukla D, Naqvi AR. CRISPR-Cas Based Targeting of Host and Viral Genes as an Antiviral Strategy. Semin Cell Dev Biol. grudzień 2019;96:53-64.

[3] Ishino Y, Shinagawa H, Makino K, Amemura M, Nakata A. Nucleotide sequence of the iap gene, responsible for alkaline phosphatase isozyme conversion in Escherichia coli, and identification of the gene product. J Bacteriol. grudzień 1987;169(12):5429-33.

[4] Adli M. The CRISPR tool kit for genome editing and beyond. Nat Commun. 15 maj 2018;9:1911.

[5] Ishino Y, Krupovic M, Forterre P. History of CRISPR-Cas from Encounter with a Mysterious Repeated Sequence to Genome Editing Technology. J Bacteriol. 12 marzec 2018;200(7):e00580-17.

[6] Makarova KS, Koonin EV. Annotation and Classification of CRISPR-Cas Systems. Methods Mol Biol Clifton NJ. 2015;1311:47-75.

[7] Barrangou R, Fremaux C, Deveau H, Richards M, Boyaval P, Moineau S, i in. CRISPR provides acquired resistance against viruses in prokaryotes. Science. 23 marzec 2007;315(5819):1709-12.

[8] Cebrian-Serrano A, Davies B. CRISPR-Cas orthologues and variants: optimizing the repertoire, specificity and delivery of genome engineering tools. Mamm Genome. 2017;28(7):247-61.

[9] Nishimasu H, Ran FA, Hsu PD, Konermann S, Shehata SI, Dohmae N, i in. Crystal Structure of Cas9 in Complex with Guide RNA and Target DNA. Cell. 27 luty 2014;156(5):935-49.

[10] Ma Y, Zhang L, Huang X. Genome modification by CRISPR/Cas9. FEBS J. grudzień 2014;281(23):518693.

[11] Hryhorowicz M, Lipiński D, Zeyland J, Słomski R. CRISPR/Cas9 Immune System as a Tool for Genome Engineering. Arch Immunol Ther Exp (Warsz). 2017;65(3):233-40.

[12] Wilbie D, Walther J, Mastrobattista E. Delivery Aspects of CRISPR/Cas for in Vivo Genome Editing. Acc Chem Res. 18 czerwiec 2019;52(6):1555-64.

[13] Refaey ME, Xu L, Gao Y, Canan B, Adesanya TMA, Warner SC, i in. In Vivo Genome Editing Restores Dystrophin Expression and Cardiac Function in Dystrophic Mice. Circ Res. 29 wrzesień 2017;121(8):9239.

[14] Xie J, Wei J, Lv L, Han Q, Yang W, Li G, i in. Angiopoietin-2 induces angiogenesis via exosomes in human hepatocellular carcinoma. Cell Commun Signal CCS. 17 marzec 2020;18:46.

[15] Yoon A-R, Jung B-K, Choi E, Chung E, Hong J, Kim J-S, i in. CRISPR-Cas12a with an oAd Induces Precise and Cancer-Specific Genomic Reprogramming of EGFR and Efficient Tumor Regression. Mol Ther. 7 październik 2020;28(10):2286-96.

[16] Jubair L, Lam AK, Fallaha S, McMillan NAJ. CRISPR/Cas9-loaded stealth liposomes effectively cleared established HPV16-driven tumours in syngeneic mice. PLOS ONE. 7 styczeń 2021;16(1):e0223288.

[17] Dumeau C-E, Monfort A, Kissling L, Swarts DC, Jinek M, Wutz A. Introducing gene deletions by mouse zygote electroporation of Cas12a/Cpf1. Transgenic Res. 2019;28(5):525-35.

[18] Sheets TP, Park C-H, Park K-E, Powell A, Donovan DM, Telugu BP. Somatic Cell Nuclear Transfer Followed by CRIPSR/Cas9 Microinjection Results in Highly Efficient Genome Editing in Cloned Pigs. Int J Mol Sci. 3 grudzień 2016;17(12):2031.

[19] Uddin F, Rudin CM, Sen T. CRISPR Gene Therapy: Applications, Limitations, and Implications for the 
Future. Front Oncol. 7 sierpień 2020;10:1387.

[20] Savić N, Schwank G. Advances in therapeutic CRISPR/Cas9 genome editing. Transl Res J Lab Clin Med. luty 2016;168:15-21.

[21] Liu C, Zhang L, Liu H, Cheng K. Delivery strategies of the CRISPR-Cas9 gene-editing system for therapeutic applications. J Control Release Off J Control Release Soc. 28 listopad 2017;266:17-26.

[22] Cyranoski D. CRISPR gene-editing tested in a person for the first time. Nature. 24 listopad 2016;539(7630):479.

[23] Baliou S, Adamaki M, Kyriakopoulos AM, Spandidos DA, Panayiotidis M, Christodoulou I, i in. CRISPR therapeutic tools for complex genetic disorders and cancer (Review). Int J Oncol. 6 czerwiec 2018;53(2):443-68.

[24] Manguso RT, Pope HW, Zimmer MD, Brown FD, Yates KB, Miller BC, i in. In vivo CRISPR screening identifies Ptpn2 as a cancer immunotherapy target. Nature. 27 lipiec 2017;547(7664):413-8.

[25] Lentsch E, Li L, Pfeffer S, Ekici AB, Taher L, Pilarsky C, i in. CRISPR/Cas9-Mediated Knock-Out of KrasG12D Mutated Pancreatic Cancer Cell Lines. Int J Mol Sci. 14 listopad 2019;20(22):5706.

[26] Watanabe S, Shimada S, Akiyama Y, Ishikawa Y, Ogura T, Ogawa K, i in. Loss of KDM6A characterizes a poor prognostic subtype of human pancreatic cancer and potentiates HDAC inhibitor lethality. Int J Cancer. 1 lipiec 2019;145(1):192-205.

[27] Digomann D, Kurth I, Tyutyunnykova A, Chen O, Löck S, Gorodetska I, i in. The CD98 Heavy Chain Is a Marker and Regulator of Head and Neck Squamous Cell Carcinoma Radiosensitivity. Clin Cancer Res Off J Am Assoc Cancer Res. 15 maj 2019;25(10):3152-63.

[28] Jiang F-N, Liang Y-X, Wei W, Zou C-Y, Chen G-X, Wan Y-P, i in. Functional classification of prostate cancer-associated miRNAs through CRISPR/Cas9-mediated gene knockout. Mol Med Rep. listopad 2020;22(5):3777-84.

[29] Lovnicki J, Gan Y, Feng T, Li Y, Xie N, Ho C-H, i in. LIN28B promotes the development of neuroendocrine prostate cancer. J Clin Invest. 130(10):5338-48.

[30] Ercolano G, De Cicco P, Rubino V, Terrazzano G, Ruggiero G, Carriero R, i in. Knockdown of PTGS2 by CRISPR/CAS9 System Designates a New Potential Gene Target for Melanoma Treatment. Front Pharmacol. 5 grudzień 2019;10:1456.

[31] Chira S, Gulei D, Hajitou A, Zimta A-A, Cordelier P, Berindan-Neagoe I. CRISPR/Cas9: Transcending the Reality of Genome Editing. Mol Ther Nucleic Acids. 8 kwiecień 2017;7:211-22.

[32] Janik E, Niemcewicz M, Ceremuga M, Krzowski L, Saluk-Bijak J, Bijak M. Various Aspects of a Gene Editing System-CRISPR-Cas9. Int J Mol Sci. 16 grudzień 2020;21(24):9604.

[33] Gupta RM, Musunuru K. Expanding the genetic editing tool kit: ZFNs, TALENs, and CRISPR-Cas9. J Clin Invest. 1 październik 2014;124(10):4154-61.

[34] Fu Y, Foden JA, Khayter C, Maeder ML, Reyon D, Joung JK, i in. High frequency off-target mutagenesis induced by CRISPR-Cas nucleases in human cells. Nat Biotechnol. wrzesień 2013;31(9):822-6.

[35] Baylis F, McLeod M. First-in-human Phase 1 CRISPR Gene Editing Cancer Trials:Are We Ready? Curr Gene Ther. sierpień 2017;17(4):309-19.

[36] Mulvihill JJ, Capps B, Joly Y, Lysaght T, Zwart HAE, Chadwick R, i in. Ethical issues of CRISPR technology and gene editing through the lens of solidarity. Br Med Bull. 1 czerwiec 2017;122(1):17-29. 